\title{
Acta
Biochimica
Polonica
}

Vol. 48 No. 2/2001

$367-381$

QUARTERLY

Review

\section{Reduction of bacterial genome size and expansion resulting from obligate intracellular lifestyle and adaptation to soil habitat $^{\star}$}

Tomasz Stêpkowski ${ }^{\Omega}$ and Andrzej B. Legocki

Institute of Bioorganic Chemistry Pol ish A cad emy of Sci ences, Poznañ, Po land

Received: 14 February, 2001; accepted: 9 May, 2001

Key words: ge nome, sym bi o sis, rhizobium, Buchnera, Rickettsia

Prokaryotic or gan isms are ex posed in the course of evo lu tion to var $i$ ous im pacts, $r e$ sult ing of ten in dras tic changes of their ge nome size. De pending on cir cum stances, the same lin eage may di verge into spe cies hav ing sub stan tially re duced genomes, or such whose genomes have un der gone con sid er able en large ment. Ge nome re duc tion is a con se quence of ob li gate intracellular life style ren der ing nu mer ous genes ex pend able. An other con se quence of intracellular life style is re duc tion of ef fec tive pop u la tion size and lim ited pos si bil ity of gene ac quire mentvia lat eral trans fer. This causes a state of relaxed se lection resulting in accu mu la tion of mildly del eteri ous mu ta tions that can not be cor rected by re com bi na tion with the wild type copy. Thus, gene loss is usually irreversible. Additionally, constant environment of the eukaryotic cell renders that some bac te rial genes in volved in DNA re pair are ex pand able. The loss of these genes is a prob a ble cause of mutational bias re sult ing in a high A+T con tent.

While causes of genome reduction are rather indisputable, those resulting in genome ex pan sion seem to be less ob vi ous. P re sum ably, the ge nomeen large ment is an indirect consequence of adaptation to changing environmental conditions and requires the ac qui si tion and in te gra tion of nu mer ous genes. It seems that the need for a great number of capabilities is common among soil bacteria irrespective of their phylo gen etic re la tion ship. How ever, this would not be pos si ble if soil bac te ria lacked

\footnotetext{
\# Presented at thel $n$ ter national Con fer enceon "M o lecular Ar chi tecture of Evolution, Pri mary and Secondary Determinants" Poznañ, Poland, Octo ber 29- 31, 2000.

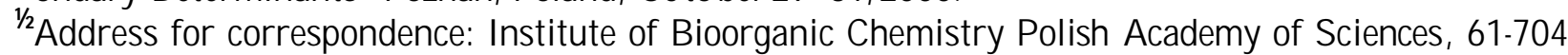
Poznañ, Z. Noskowskiego 12/14, Poland; tel.: (48 61) 852 8919; fax: (48 61) 852 0532; e-mail: sttommic@ibch.poznan.pl
}

Abbreviations: LCOs, lipochitooligosaccharides; Nfs, Nod factrors; ORF, open reading frame; SAM, S-adenosylmethionine; SFG, spotted fe ver group; T-DNA, trans ferred DNA; TG, ty phus group. 
indigenous abil i ties to ex change and ac cu mu late ge netic in for ma tion. The lat ter are considerably facilitated when housekeeping genes are physically separated from adap tive loci which are use ful only in cer tain cir cum stances.

\section{GENOME REDUCTION OF INTRA- CELLULAR OBLIGATE SYMBIOTIC AND PATHOGENIC BACTERIA}

A great number of Bacteria live solely in eukaryotic cells or tissues as chronic pathogens or mutualistic bacteriocyte associates. Some of these species, usu ally hu man (or an imal) patho gens are the ob jects of ex ten sive re search in clud ing sequencing of their com plete genomes. Two such complete genome sequences have be come avail able in recent years in public databases. The first relates to Rickettsia prowazekii Madrid E strain pathogenic to hu mans, whereas the other is Buchnera sp. ASP, a mutualistic bac te rium living in sym biosis with Aphids. There are some other obligate intracellular bacteria whose genomes should be completed in near future. They include one Buchnera aphidicola strain, at least two Rickettsia species and three Wolbachia strains. Despitedis tinct phylogen eticor i gins, all these bacteria bear certain common characteristics, directly resulting from their intracellular life style. This mode of life lim its the possi bil ity of ac qui si tion of for eign genes via lateral gene transfer. Moreover, all obligate intracellular bacteria have a much lower ef fective pop u la tion sizethan free-living ones. The small pop u la tion size causes a state of re laxed selection, thusal lowingaccumulation of moderately deleterious mutations (Wernegreen \& Moran, 1999). This phenomenon is known as near-neutral evolution or Muller's ratchet (Moran, 1996). One of the consequences of Mul ler's ratchet is ac cel er ated evolution of all gene sequences (Brynnel et al., 1998). On the other hand, the availability of com pounds in the host cell, and rel a tive safety in constant cellular environment renders many genes expendable. The consequence of these two factors is inactivation and subsequent loss of genes, which finally causes genomereduction of ten ap proach ing the low est size limits. Additionally, the loss of certain functions involved in DNA repair and recombi na tion results in a strong mutational bias to wards a high $\mathrm{A}+\mathrm{T}$ content, a feature usually as so ci ated with intracellular mode of life. All these features define the so-called "resident" genome (Andersson \& Kurland, 1998). However, obligate intracellular bacteria share some other features as well. They include a small num ber of regu la tory genes as well as a reduced amount of genes linked to uptake or trans port of the com pounds from the out side environment.

Phylogenetic analysis reveals that intracellular obligate bacteria belong to distinct and usu ally deeply branch ing lin eages. This is interpreted as the factor which pre cludes fre quent shift from sym bi otic to patho geniclife style and vice versa (Moran \& Wernegreen, 2000). Irreversible loss of genes which could con tributeto ei ther patho genic or mutualistic association appears to be the main cause of lin eage sta bil ity that is ob served in most ob ligate intracellular bacteria. Nevertheless, there are ex am ples of closely related lin eages comprising both mutualistic and pathogenic bacteria, such asFlavo bacteria, onelin eage of which con tains an ob li gate mutualist of cockroaches, whereas the other comprises male-killing par a sites in la dy bird beetles. Sim ilarly, W olbachia spp. include reproductive (male-killing) parasites of arthropods and mutualists of nematodes (Bandi et al., 1992; Hurst et al., 1996). Perhaps, for that reason genomes of Wolbachia spp. are still rather large (1.4- 1.7 Mb), suggesting that genome reduction in these bacteria is in its initial phase.

In this paper we fo cus on B uchnera which is a symbiont of Aphids and whose genome has prob a bly reached one of the low est size lim its, as well as on Rickettsia spp. in which thegenomereduction is still an on go ing pro cess. 


\section{GENOMES OF BUCHNERA APHI- DICOLA AND ITS APHID HOST ENCODE COMPLEMENTARY METABOLIC FUNCTIONS}

Buchnera spp. are endosymbionts of A phids, in which they spend their entire life inhabiting a specialized cell-line, the so-called bacteriocytes. A phylogen etic anal y sis has re vealed that this symbiotic association between Buchnera and Aphids was established some 200-250 mil lion years ago (Baumann et al., 1995; Brynnel et al., 1998; Ochman et al., 1999). Such a long time has re sulted in a close integration of their metabolisms, and complete mutual dependence of the partners on each other. It has been no ticed that B uchnera shares features of both pathogenic bacteria and eukaryotic organelles, being probably intermediate between the two (Andersson, 2000). B uchnera pro vides its host with a va riety of nu tri ents, in clud ing es sen tial amino acids, vi ta mins, and proba bly somenu cleotides (Baumann et al., 1995). Recently, a com plete, $0.64 \mathrm{Mb}$ genomic sequence of Buchnera sp. APS strain has been published (Shigenobu et al., 2000). Buchnera sp. APS strain is an endosymbiont of the pea aphid, Acyrthiosiphon pisum. This second, smallest genome published to date is composed of a circular chro mo some and two small plasmids, har boring 583 open reading frames a total. One of the plasmids carries leuABCD operon (pLeu plasmid), while the other $\operatorname{trpEG}$ operon (pTrp plasmid) (Rouhbakhsh et al., 1996; Silva et al., 1998). Thus, some genes that essentially contribute to this unique association occur in multiple copies that may positively influence the amount of the amino acids synthesized. Actually, all genes irrespective of their location are mul ti ple copy ones, since each cell of these bacteria contains an average of 120 genomic copies (Komaki \& Ishikawa, 1999). Theaver age $G+C$ con tent of $B$ uchnera ge nome is $26.3 \%$. Similarly to other prokaryotes of comparable genome size, including all intracellular B acteria, Buchnera genome har- bors single copies of $16 \mathrm{~S}, 5 \mathrm{~S}$ and $23 \mathrm{~S}$ rRNA genes and only 32 tRNA genes. The chromosome har bors 564 ORFs, with av er age size of 988 bp, which cover $88 \%$ of chromosome length. Both the ORF size and the per cent age of cod ing regions aresim i lar to those found in the majority of sequenced prokaryotic genomes. Interestingly, unlike free-living prokaryotes, the Buchnera ge nome misses insertion or phage-related sequences. This implies that lateral gene transfer played a very lim ited rolein theevo lu tion of these bac teria, as well as that there was a strong pres sureto eliminate redundant or expendable sequences. Buchnera sequences have been the first published ones, and majority of them have their counterparts in the database: For 500 out of 583 ORF s a func tion based on sim ilarity searches in the database could be assigned. For other 79 ORFs, similar genes albeit of unknown functions were found, while only four ORFs appear to be unique. As expected, the majority of most similar ORFs origi natefromE scherichia coli, which is phylogenetically most related among all fully sequenced Bacteria (Shigenobu et al., 2000).

Genomeanal ysishas revealed that B uchnera harbors genes for biosynthesis of essential amino acids, while those which are responsible for nonessential amino acids are almost completely missing. Thus, Buchnera possesses only those genes which are lacking in the host genome. Similar mutual dependence can be found for pantothenate-coenzyme $A$ (COA) biosynthesis. The genes for pantothenate are present in Buchnera, while the host cells lack such functions. On the other hand, no genes for the pathway from pantothenate to CoA were found in Buchnera, while the eukaryotic cell ex presses this part of the path way. For that rea son, find ing of only a few genes in volved in trans port was rather unexpected. Besides, Buchnera genome carries only a few genes for cell-surface components, since the host pro vides some com po nents necessary for lipopolysaccharide synthesis. There are also only a few genes encoding 
outer membrane proteins and lipoproteins. Scar city of genes cod ing for cell sur face components renders Buchnera cells vulner ableto environmental challenges and fully dependent on its host's cells (Shigenobu et al., 2000).

Another peculiarity of Buchnera genome is the lack of recA, lexA, umuCD, and uvrABC genes, which are responsible for homologous recom bi nation and DNA repair, as well as the lack of genes involved in DNA methylation and restriction. Presum ably, thelack of these genes is responsible for mutational bias towards a high AT con tent, which is usu ally observed among intracelullar species (Moran \& W ernegreen, 2000).

\section{GENOME DEGRADATION IN RICKETTSIA}

R ickettsia spp. are ob li gate intracellular para sites that belong to the al pha proteobacteria. These bac teria are usu ally as so ci ated with arthropods, from which they are trans fer to humans (Raoult \& Roux, 1997). This genus can be divided into two groups: one (the typhus group or TG) comprises R. prowazekii and R. typhi spp., which are pathogenic to humans and mice, while the other so-called spot ted fe ver group (SFG) includes $\mathrm{R}$. rickettsii, a species known as an etiological agent of Rocky Mountain spotted fever. Rickettsia genomes are larger than those of Buchnera, and range from 1.1 to $1.4 \mathrm{Mb}$. Presumably, this genus originates from a free-living ancestor whose genome was much larger (Andersson et al., 1998). The ge nome of $R$. prowazekii strain $\mathrm{Ma}$ drid $E$ con tains 834 com pleteOR $F$ s of av er age length $1005 \mathrm{bp}$. A biological role has been assigned to $62.7 \%$ of ORFs, while $12.5 \%$ have similar counterparts although of unknown function. In ter est ingly, this genomecar ries a much higher proportion of non-coding sequences (24\%) than most prokaryotic chro mosomes char ac ter ized to date, the av er age percentage for which is about $10 \%$. Only small fractions of $\mathrm{R}$. prowazekii non-coding sequen- ces, i.e., $0.9 \%$ and $0.2 \%$ are represented by pseudogenes or non-coding repeating sequences, respectively. The remaining $22.9 \%$ do not code for proteins composed of more than 100 amino ac ids. A small num ber of re iterated sequences is common among obligate intracellular bacteria, moreover, all these sequences are rel a tively short ( $<500 \mathrm{bp})$, and occur in intergenic regions. $A$ low $\mathrm{G}+\mathrm{C}$ content (mean $23.7 \%$ ), slightly lower than the av er age for the whole ge nome (29.1\%) is a char ac ter is tic feature of non-coding sequences.

Con sistently with other find ings con cern ing ob li gateintracellular bacteria, thenum ber of genes involved in biosynthetic pathways in $\mathrm{R}$ ickettsia is highly re duced. This con cerns the genes respon si blefor amino acid syn thesis, as well as those genes in volved in de novo syn the sis of nucleosides. The latter are most likely taken up from the host cell cytoplasm in the form of monophosphates, which later are converted into di-and triphosphates by en zy matic machinery of the pathogen. Unlike in Buchnera, Rickettsia genome harbors a full complement of genes coding for tricarboxylic acid cy cle- respi ra tory chain com plexes. It includes also ATP/ADP translocases that enable the up take of ATP di rectly from the host in ini tial stages of in fection.

Like Buchnera, R. prowazeki carries genes encoding $\alpha, \beta$, and $\beta^{\prime}$ subunites of RNA polymerase, and $\sigma^{70}$ and $\sigma^{32}$ factors. Thelat ter is ab sent in the ma jor ity of small genomes such as those of Borrelia burdorferi, Helicobacter pylori, Chlamydia trachomatis although these bac te ria haveheat shock en cod ing genes ( $\mathrm{Alm}$ et al., 1999; Fra ser et al., 1997; Stephens et al., 1998; Tomb et al., 1997). Likewise, Rickettsia has fewer genes involved in DNA repair and recombination, for instance mutH, mutY genes and recBCD operon are missing.

The genome of R ickettsia has 21 genes coding for 18 out of 20 aminoacyl-tRNA synthetas es which are nec es sary for pro tein syn the sis. The genes encoding glutaminyl-tRNA $(\mathrm{g} \mid \mathrm{nS})$ and asparaginyl-tRNA (asnS) synthetases are missing. This suggests that, like in 
the majority of Bacteria, GIn-tRNAs and Asn-tRNAs are formed following transamidation reactions of glutamic and apartic acids, respectively (Handy \& Doolittle, 1999).

Like in other intracellular obligatebacteria, the number of regulatory genes in Rickettsia seems to be significantly reduced. Among these genes are a few members of two-component regulatory systems, such as barA, envZ, ntrY, ompR and phoR, all of which are also miss ing in $B$ uchnera genome.

Unlike Buchnera, Rickettsia genome has most genes involved in lipopolysaccharide synthesis, including IpxA, IpxB, IpxC, IpxD genes. This genome contains most genes implicated in ketodeoxyoctonate synthesis (including kdsA, kdsB and kdtA), and several genes cod ing for outer mem brane pro teins. It carries genes involved in protein excretion such as secA secB, secD, secE, secF, secG and $\mathrm{ffH}$ genes. In comparison, Buchnera genome has $\sec A$, secB, secE, secG, and $\mathrm{ffH}$, but not $\sec C$, secD, and secF genes (Shigenobu et al., 2000).

The molecular basis of pathogenicity is still unclear. Nevertheless, the genome analysis has revealed two types of genes whose homologs may belong to prin ci pal factors render ing the bac te rium patho genic. The first re lates to virB homologs of Agrobacterium tumefaciens, in which genes of this type are asso ci ated with trans fer of T-DNA (K ado, 2000). How ever, the lack of virD2 and virE 2, which in A. tumefaciens encode proteins conferring DNA transfer by binding to single-stranded T-DNA, may sug gest yet an other role. I t seems likely, especially taking into account that homo logues of virB genes in B ordetella per tus sis and $H$. pylori are related to protein secretion. Thus, in $\mathrm{R}$. prowazekii these virB homologs may be involved in both conjugal DNA transfer and protein export. Two other putative determinants of pathogenicity are homologousto capD and capM genes of Staphylococcusaureus, in which these two genes participate in synthesis of capsular polysaccharide, which is one of the prin ci pal deter- minants of pathogenicity in this species (Lin et al., 1994).

Unlike other obligate intracellular bacteria whose genome sequences have been determined in re cent years, $R$. prowazekii car ries a much higher proportion of non-coding sequences. This indicates that in this group of bacteriathegenomereduction is still an on go ing pro cess. This may im ply thatR ickettsia ances tors for a much lon ger time havere mained in at least par tially free-living state than other ob li gate intracellular spe cies. The most striking example of initial evolutionary processes that lead to gene inactivation comes from a comparison of gene sequences coding for S-adenosylmethionine synthetase (metK) in several Rickettsia spp. This gene has housekeeping function and the encoded enzyme is responsible for biosynthesis of S-adenosylmethionine (SAM), a substrate necessary for methylation processes (Newman et al., 1998). In most of the Rickettsia species analysed, this gene is inactive although in each case the mutation has distinct nature (Andersson \& Andersson, 1999).

\section{SYMBIOTIC NITROGEN FIXATION WITH LEGUMINOUS PLANTS IS A FEATURE THAT IS LARGELY CONFINED TO THE ALPHA PROTEOBACTERIA}

Like Rickettsia, all rhizobia belong to alpha proteobacteria. Currently, this group of symbiotic bacteria is classified into the genera: Allorhizobium, A zorhizobium, Bradyrhizobium, Mesorhizobium, R hizobium and Sinorhizobium (Broughton \& Perret, 1999; van Berkum \& Eardly, 1998). H owever, the identification of M ethylobacterium nodulans ex tends the scope of this sym bi o sis onto an other group of theat pha proteobacteria (Sy et al., 2001). A unique prop erty of sym bi otic ni tro gen fix a tion by le gumes and rhizobia is the formation of nodules on the roots, or, in some cases, also on the stems. The nodules are novel plant organs 
whose main, and presumably the only function, is nitrogenfixation. Within these structures the rhizobia undergo transformation into bacteroids that are able to fix atmospheric ni tro gen. Al though the le gume determines a nod ule type and a site of nod ule formation, a signal molecule that triggers nodule formation is produced by a rhizobium. Bacterial signals are lipochitooligosaccharides known as Nod factors (NFs or LCOs) (Lerouge et al., 1990). There are two main fea tures which areas so ci ated with Nod factors. One concerns the recognition process that allows a legume plant to select its proper microsymbiont, while another is induction of divisions of meristematic cells in the root tissues, which in consequencegives rise to a nodule.

Noteworthy is the fact that the majority, if not all genera of rhizobium have diverged prior to the emergence of leguminous plants, which occurred not earlier than 140 million years ago. Taking into account that the most phylogenetically distant Bradyrhizobium genus diverged from the last common ancestor of all rhizobia some 500 mil lion years ago, i.e., well before the emergence of land plants (Turner \& Young, 2000), it is apparent that during most of the time these rhizobia were non-symbiotic. Presumably, the same might be said about the remain ing gen era. One can only spec u late about rhizobium life style prior to the emergence of legumes. Nonetheless, therearesug ges tions that they may have been soil saprophytes, possibly living in the rhizosphere or in an endophytic association with plants (Chaintreuil et al., 2000). In contrast to obligate intracellular bacteria, the intracellular stage in this case is limited to a fraction of all cells that multiply in the rhizosphere, or within the plant root. This is logical, since transformation into bacteroids is presumed to be irreversible. For this reason, like other soil bacteria, rhizobia must carry nu mer ous genes nec es sary for living in soil, being more over equipped with functions allowing for invasion into and survival in an eukaryotic cell. The latter ability might be a very ancient one, possibly carried even since the time preceding the appearance of mitochondria (Andersson et al., 1998).

\section{ORGANIZATION OF RHIZOBIUM GENOME FACILITATES ACQUISITION OF FOREIGN GENES NECESSARY TO COPE WITH ADVERSE ENVIRONMENTAL CONDITIONS}

Apparently, living in soil is something very different from life in a rather constant eukaryotic cell environment. Thus, a rhizobium cell is usu ally well adapted to var i ous adverse con di tions such as suboptimal tem per a tures, drought (or ex cess of wa ter), sa lin ity, at ka line or acid con di tions. More over, living in an environment which is poor in nutrients, they must be able to compete with other micro or gan isms, some of which pro ducetoxic or inhibitory compounds. As could be expected, rhizobium ge nome har bors all thesefunctions that are necessary to survive in such a rigid en vi ron ment. It in cludes the abil ity to syn the size cell components from simple substrates and to use numerous compounds as energy, carbon and nitrogen sources. Additionally, the rhizobium must be equipped with a number of genes involved in quorum-sensing, intercellular com mu ni cation and signal ing, as well as with a number of regulatory, uptake and secretion genes. To accommodate all these func tions, rhizobia are ex pected to have larger genomes than the spe cies se quenced to date. Indeed, the genome of Bradyrhizobium japonicum USDA110 has been assessed to be of $8.7 \mathrm{Mb}$ (Kundiget al., 1993), the size that is close to the largest prokaryotic genomes of Myxococcus xanthus and Stigmatella aurantiaca, whose sizes have been estimated for 9.2 $\mathrm{MB}$ and 9.2-9.9 $\mathrm{Mb}$, respectively (Casjens, 1998). Actually, the 7.6 M b-large ge nome of Mesorhizobium loti MAFF 303099 strain is the largest prokaryotic one completed to date (Kaneko et al., 2000). 
Genome expansion would not be possible with out lat eral genetrans fer. Actually, lateral gene transfer seems to be the major force responsible for shap ing gene con tent and or ga ni za tion of prokaryotic genomes. It is also the most effective mechanism responsible for acquisition of foreign genes that are necessary for oc cu pa tion of a novel niche (Ochman et al., 2000). Some bacterial species show the linkage equilibrium, which implies a high frequency of recombination caused by lateral gene transfer (Smith et al., 1993). However, "novel" genes, if not car ried by a broad range plasmid, rarely find ho mol o gous sequences in the re cip i ent genome. In such cases, their suecessful in tegration usu ally depends on recombi nation (ei ther legiti mateor il legiti mate) me diated by other mobile elements, such as insertion sequences, transposons or phages (Ochman et al., 2000). Genomeanal y sis shows that mo bileel ements, as well as reit er ated and other accessory sequences are not randomly dis tributed, but arelo cated mainly in dis crete regions known as recombination hot spots (Romero et al., 1991). Such a state could be caused by a pure chance al though it might be also an in di rect con sequence of selection. It is con ceiv ablethat thepres ence of housekeep ing genes on a plasmid may indirectly limit the number of those DNA elements, which enhance genomic instability, rendering such plasmid more stable. This in turn may favor the acquisition of other housekeeping genes, result ing in the fi nal change of its sta tus from "accessory" to "chromosomal". In this way some plasmids may have evolved into a second chromosome. On the contrary, the lack (or loss) of housekeeping genes makes more likely an accu mulation of acces sory el ements, since a higher level of genomic in sta bil ity has a lim ited ef fect on cell fit ness, if de letions are confined only to expendable sequences. Probably, the same logic could be applied to explain the mosaic character of chromosomes, where adap tive genes are of ten not only sep a rated from house keep ing ones, but are also located in regions rich in insertion elements, transposons and reiterated sequences. Thus, de letions that are of ten formed dur ing recombi nation events en com pass mostly non-coding sequences or genes that are dis pens able. This allows the integration of numerous genes without loss of the essential ones (Moxon et al., 1994). An other mech anism of ten reported in the regions which bear genes related to pathogenicity, exploits tRNA genes as target sequences for integration through homologous recombination. Such discrete regions usually flanked by two direct tRNA gene repeats aretermed patho genic ity is lands. Their distinct $\mathrm{G}+\mathrm{C}$ content, as well as the presence of integrase (and other mo bil ity loci), and ge netic instability argue for the generation of patho genicity is lands by lat eral genetransfer, a pro cess that is well known to contribute to microbial evolution (Hacker \& Kaper, 2000). High level of conservation of tRNA gene sequences makes them ideal targets for recombination of DNA fragments, even when a sequence orig i nates from a phylo gen eti cally dis tant species. Although most newly acquired sequences are neutral or deleterious, and therefore are lost (or the bacteria harboring them become outcompeted), some may ultimately de velop into a func tion that al lows occupation of a novel niche. Thus, the mosaic structure of chromosomes and plasmids, as well as a dis tinct se lec tivesta tus of par ticu lar regionsfacilitategenomeplasticitynecessary for adaptation to changing environment and reduce the costs related to this process. Finally, this is one of the mech a nisms re sponsible for the increase of genome size.

\section{SYMBIOSIS PLASMIDS, ISLANDS AND REGIONS}

Sym bi oticni trogen fixation isa "com posite" function. Con ven tionally, sym bi oticgenes are divided into two groups: genes involved in nodulation (nod, nol and noe), and those related to nitrogen fixation (nif and fix). All these genes belong to "adap tive" loci, i.e., they 
seem to bedis pens ablefor cell function ing (at least in laboratory conditions) but enable occu pation of a dis creteeco logi cal niche (Perret et al., 2000; Preston et al., 1998). In some rhizobia, the major ity of sym bi otic loci are located on an in dig enous plasmid, the so-called sym bi o sis, or Sym plasmid. It seems that such location of symbiotic functions occurs in all species belonging to the genera Rhizobium and Sinorhizobium, as well as in many Mesorhizobium spp., while in Azorhizobium, $B$ radyrhizobium and $M$ esorhizobium loti sym biotic genes are located on the chromosome (Schlaman et al., 1998).

Although more than 60 genes directly involved in nodulation have been identified to date, a given strain carries only 15-20 nod genes (Schlaman et al., 1998). There is no single gene arrangement of nodulation loci. The most frequently found is composed of three common nodA, nodB and nodC genes (occur in all rhizobia) which are fol lowed by nodl and nodd, both involved in Nod factor transport, as well as by a few hsn (host specificity nodulation) genes responsible for chemical modifications of the Nod factor (M ergaert et al., 1997). Such nod gene oper on is un der control of nodD gene of the LysR family of prokaryotic transcriptional regulators (Downie, 1998). Interestingly, the nodulation clusters have not been reported in organisms other than the rhizobia, albeit somewhat lower $\mathrm{G}+\mathrm{C}$ content of nodulation genes in comparison to $\mathrm{G}+\mathrm{C}$ content of non-symbiotic loci could sug gest the op po site. While the or igin of nodulation functions remains unknown, some Nod pro teins show a dis tant similarity to proteins found in unrelated organisms.

The presence of non-symbiotic rhizobia clones in natural populations has suggested that the loss of symbiotic loci has rather a moderate effect on strain survival. Although this issue deserves additional studies, those car ried out so far in di cate that non-symbiotic rhizobia may con sti tutethemajor ity of clones in soil populations (Segovia et al., 1991). The recurrent loss and acquisition (via lateral transfer) of symbiotic loci could have some evolutionary significance provided that such functions are organized as dis crete gene clusters. Actually, lateral gene transfer seems to be a major factor responsible for clustering genes into functional operons (Preston et al., 1998). While curing of symbiosis plasmid is gen er ally easy, a derivativeofs. meliloti missing pSym megaplasmid has been reported very recently, suggesting the presence of genes which in flu ence the growth rate even in a rich medium (Oresnik et al., 2000). Sym biotic genes can be harbored by a $1200 \mathrm{~kb}$ (or larger) replicon, i.e., some of them are larger than the whole prokaryotic chromosomes. The symbiosis plasmids differ significantly even among closely re lated strains, how ever it seems rather unlikely that the main cause of dif fer ences is the num ber of sym bi otic genes (Baldani et al., 1992; Hynes \& McGregor, 1990). Actually, earlier studies have suggested that a small num ber of genes is nec essary for development of effective symbiosis. For instance, the nod-nif-fix re gion on $180 \mathrm{~kb}$ pSym (plasmid a) of R. leguminosarum bv. trifolii ANU843 is confined to a $32 \mathrm{~kb}$ DNA frag ment (Innes et al., 1988). How ever, pSym of ANU 843 lacks some es sen tial genes, e.g., it misses the fixN OQP operon, there fore such a conclusion on the limited number of symbiotic genes may not be jus ti fied. Actually, taking into ac count only recent se quenc ing data, there could be as many as several hundred genes. For such conclusion seems to indicate thestud ies con cern ing thesym bi osis regions (both plasmids and is lands) in Sinorhizobium sp. NGR234, M. loti strains and in B. japonicum USDA110, all of which comprise DNA fragments of $>400 \mathrm{~kb}$ (Freiberg et al., 1997; Göttfert et al., 2001).

In M. loti the chromosomal symbiotic genes form the so-called symbiosis island. Unlike other symbiotic regions, a symbiosis island car ries genes respon si blefor ex ci sion and integration within the target phenylalanine tRNA gene sequence (Sullivan \& Ronson, 
1998). Both excision and integration are carried out by an integrase of the phage $\mathrm{P} 4 \mathrm{fam}$ ily. Importantly, neither of these two processes disrupts the continuity of tRNA gene. Actually, the is land in tegrates into phe-tRNA gene, recon struct ing the gene at the integrase end and form ing a $17 \mathrm{bp}$ re peat of the $3^{\prime}$ end of phe-tRNA at the other end of this island. Additionally, the island harbors genes involved in biosynthesis of bi otin, thi a mineand nicotinate for which non-symbiotic clones are auxotrophic. This gives a selective advantage over non-symbiotic clones even prior to the onset of symbiosis, explain ingthedissemina tion of the symbiotic genes among cognate Mesorhizobium strains. This $>500 \mathrm{~kb}$ DNA frag ment car ries all genes which are known to be associated with symbiosis including fixNOQP, fixGHIS, exSBCD and $\operatorname{dct} A B D$ operons, which usu ally are not car ried by symbiosis plasmids, as well as many other genes of largely unclear function. It is noteworthy that, the genome of M. Ioti MAFF 303099 carries a cer tain num ber of genes, the find ing of which was rather unexpected. To such genes belong nodE, and nodF as well as nodG, nodP and nodQ genes. The presence of well conserved nodE, nodf together with nodZ, nolL genes is surprising as the $\alpha-\beta$ unsaturation of Nod fac tor fatty acid chain (for which nodE and nodF are re spon si ble) has not been so far reported in rhizobia whose Nod factor reducing end is glycosylated (in this case it carries acetylfucose) (Downie, 1998; Kaneko et al., 2000). The presence of acetylfucose moiety, which is conferred by nodZ and nolL genes, ap pears to bea cru cial modi fi cation respon si blefor rec og ni tion of $L$ otus (or lupine) plants by M. Ioti (Lopez-Lara et al., 1995; Stacey et al., 1994). Although, in this strain, the genes related to specific modi fi cation sof N od factor fatty acyl chains presumably are inactive (or silenced), their presence potentially gives to the strain a possibility to infect (or adapt to) those legumes species which recognize distinct unsaturation levels. This may happen pro vided that gene(s) for in stancenodZ, is in- activated. That this could be the case, is shown by rather recent inactivation of noeE gene, whose still well-preserved sequence remains in the $410 \mathrm{~kb}$-long symbiotic region of B. japonicum USDA110. The noeE gene encodes a sulfotransferase specific for fucosylated Nod factors. In ter estingly, sul fation of fucosemol eculewhich is pres ent at Nod factor reducing end has never been re ported in soybean rhizobia (Carlson et al., 1993; Hanin et al., 1997; Quesada-Vincens et al., 1998). Thus, the loss of noeE gene may be regarded as a specific adaptation towards the soybeans. This symbiotic region carries some other genes whosein ac ti va tion took place rather re cently. They in clude for in stance, a few genes involved in hydrogen uptake (hupD, hupH, hupk, hypA and hypB), several genes encoding type III protein secretion system, and a gene in volved in trans port of branched amino acids ( $\mathrm{braC}$ ). It is not clear whether the loss of these genes had any im pact on sym bi o sis, or if genes of simi lar function com pen satefor their loss. Nev er the less, this also sug gests that certain genes may be linked to symbiosis loci rather accidentally, probably the linkage resulting from co-transfer with the symbiotic genes.

It seems that symbiosis regions can significantly differ even among closely related rhizobia. In lu pine-nodulating B radyrhizobium sp. WM9, a DNA fragment carrying most nodulation and a few nitrogen fixation genes has the same gene con tent and gene ar range ment as that of $B$. japonicum USDA110. However, apart from the genes present in both strains, the symbiosis clusters of Bradyrhizobium sp. W M 9 carry genes which are not present on the $400 \mathrm{~kb}$ symbiosisregion of $B$. japonicum USDA110. Moreover, nucleotide sequences of nodulation genes of $B$ radyrhizobium sp. WM 9 are much less similar with respect to nod genes of $B$. japonicum USDA 110 than the lat ter are to $B$. elkanii, and nod gene phylogeny contradicts thephylogenydeduced upon analysis of nonsymbiotic genes. In this case, Bradyrhizobium sp. WM9 and B. japo- 
nicum USDA110 are in the same branch on 16S rRNA and dnaK phylogenetic trees (Legocki et al., 1997; Sikorski et al., 1999; Stêpkowski et al., 2001).

To some degree, various proportions of non-coding se quences, in ser tion and other accessory elements may be responsible for differences in size among symbiosis plasmids. This seems to be the case, since (as it has been discussed above) symbiosis clusters, like other adaptive loci carry more insertion and mo saicel ements than thosemainly com posed of thehousekeep ing genes. Thesequencing of symbiosis regions in Sinorhizobium sp. NGR234, M. loti and B. japonicum fully confirms this as ser tion. In all these species, in sertion and mosaic elements make up approximately one-fifth of the total symbiotic sequence. Most insertion sequences or mosaic elements are clustered, and some flank the functionally important genes, implying that these genes have been ac quired by re cent lateral gene transfer. Interestingly, some repeated sequences are suf fi ciently preserved to be potential targets for homologous recombina tion; more over, some of them have coun terparts in the genomes of other rhizobium species (Göttfert et al., 2001). In the sym bi otic re gion of USDA110, several copies of well-preserved in ser tion el e ment (all in the same orien ta tion), referred to as RS $\alpha$ flank the genes related to hydrogen uptake, nif-fix cluster, typelll pro tein ex cretion geneclus ter, as well as nod-nol-noe nodulation cluster, respectively, im plying that thesedis tinct cat ego ries of sym bi otic genes may have been ac quired independently. Such "modular" arrangement fa cil i tates ac cu mula tion of var i ous genes, further emphasizing the "composite" character of sym bi o sis loci.

\section{SYMBIOSIS PLASMID OF SINORHIZOBIUM SP. NGR 234}

The se quencing of the sym bi o sis plasmid of Sinorhizobium sp. NGR234 was a mile stone in the studies on symbiotic nitrogen fixation (Freiberg et al., 1997). This strain char acterizes the broadest host range among known rhizobium spp., comprising more than 300 spe cies of 112 gen era (Pueppke \& Broughton, 1999). Themolecular ba sis for such ex tremely broad nodulation potential is still an unresolved issue. At least in part, it results from NGR234 unique ability to produce a much higher num ber of var i ous N od fac tors (mostly dif fer ing at their re ducing end) than any other rhizobium sp. (Berck et al., 1999; J abbouri et al., 1998; Perret et al., 2000; Price et al., 1992; Quesada-Vincens et al., 1998). Nevertheless, this broad host range must be determined by some unrecognized factors as well, since the closely related $\mathrm{S}$. fredii (shares $>95 \%$ sequence identity with nodulation genes of NGR234) nodulates many species of Legu minosae, even though it pro duces only one or two types of Nod factors. However, all legumes infected by $S$. fredii are nodulated by NGR234 (Pueppke \& Brough ton, 1999). Probably, most legumes nodulated by these two rhizobium species are promiscuous plants that tolerate various NFs. Nevertheless, nodulation of certain legumes requires the presenceofin trinsicmodificationsconferred by host specificity genes, which are present exclusively in NGR234 (Berck et al., 1999; Hanin et al., 1997).

The sym bi o sis plasmid of NGR234 is $536 \mathrm{~kb}$ large, i.e., its size is close to the smallestknown genome of Mycoplasma genitalium (Fra ser et al., 1995). Out of its 416 open reading frames, 136 lack similarity to any known protein in the database. For the majority of the re main ing 280, the role is still rather the 0 reti cal, based upon predictions of biochem i cal functions of their most similar counterparts in the database. However, what seems to be important, neither of the genes found in this symbiosis plasmid is related to tran scription, translation or primary metabolic functions. This fact ex plains why sym bi o sis plasmid can be eliminated from the cell. The nodulation genes are uniquely arranged into three dis- 
tinct clusters (hsnl, hsnll and hsnlll), all dispersed around the whole plasmid (Freiberg et al., 1997). This plasmid car ries all genes that areim pli cated in mod i fi ca tions of theN od factor, including those that encode fucose transferase (nodZ), and fucose-specific; acetyl (nolL), methyl (noel ), and sul fate (noeE ) transferases. However, the plasmid misses some symbiotic genes, e.g., nodEG, and nodPQ nodulation genes, as well as fixNOQP and fixG HIS operons. Thelat ter two are nec es sary for res pi ration un der microaerobiccon di tions that occur in noduleduring ni trogen fixation (Preisig et al., 1993).

Per haps, the most es sen tial find ing was the iden ti fi ca tion of many genes never beforeimplicated in symbiosis. Transcriptional analysis has revealed expression of 247 ORFs, while the remaining 169 ORFs, i.e., nearly $40 \%$ were either inactive genes, or their expression was undetectable or uninduced under conditions tested. Out of the expressed ones, only 22 (mostly in ser tion-related genes) were constitutive. Intriguingly, daidzein (a flavonoid) induced expression of as many as 147 ORFs, among which nodulation genes constituted only 20 . While nodulation genes were expressed during the first hours of induction, the majority of the remaining daidzein-induced ORFs were maximally expressed af ter $24 \mathrm{~h}$. Al most all daidzein-in ducible genes were under con trol of nod box el e ments. However, only 5 nod boxes precede nodulation genes, two are not functional, while the remaining 12 regulate the expression of genes whose roles have yet not been elucidated. Among genes whose expression was not under control of nod box elements were ORFs involved in rhamnose synthesis (Hurst et al., 1996).

The study of Perret et al. (1999), has revealed a number of genes expressed in the nodule under control of NifA- $\sigma^{54}$ promoters, as well as those regu lated in a NifA $\sigma^{54}$ in de pendent manner. In addition, certain differ- ences were found in gene ex pres sion pat terns in determinate and indeterminate nodules. For instance, 20 ORFs including nodD 1 and genes coding for components of $A B C$ transporters and trehalose synthesis, respectively, werein duced only in deter mi natenod ules. In con trast, much fewer genes were found ex clusively in indeterminate nodules. Most noduleexpressed genes com prise a $55 \mathrm{~kb}$ clus ter that harbors $10 \mathrm{NifA}-\sigma^{54}$-dependent promoters. Among the remaining six NifA- $\sigma^{54}$ promoters, oneregu lates theex pression of a clus ter carrying cytochrome P450 operon, while two others control two opposing operons (y4nGHIJ and $y 4 n M N)$, both involved in sugar metabolism. Subtractive DNA hybridiza tion has shown which genes are miss ing in S. fredii. Among them are not only nolL or noeE (both linked to specific fucose modifications), but also genes in volved in sugar transport, as well as sugar epimerase (y4nG) and aminotransferase (y4uB) genes.

More detailed studies conducted for a few genes havecon firmed their sym bi otic signif cance. Among them, the genes involved in type III pro tein ex cretion sys tem (TTSS) at tracted the greatest attention. The TTSS genes were previously described in various (un related) pathogenicbacteria, implyinglateral trans fer as a way of their dis sem i nation among distant species. In NGR234, type III excretion may be one of the key determinants responsible for the broad host range (Viprey et al., 1998). Mutations in TTSS genes abolish secretion of at least two proteins ( $\mathrm{y} 4 \mathrm{XL}$ and $\mathrm{NolX}$ ) and strongly affect nodulation of a va ri ety of trop i cal legumes including Pachyrhizus tuberosus and Tephrosia vogelii. The pres ence of these genes on sym biosis plasmid suggests that similar mechanisms function in both sym bi otic and pathogenic associations. It can be assumed that also some other genes har bored by sym bi otic plasmid may have primarily evolved in a pathogenic association. 


\section{R E E R E N CE S}

Alm, R.A., Ling, L.S., Moir, D.T., King, B.L., Brown, E.D., Doig, P.C., Smith, D.R., Noonan, B., Guild, B.C., de J onge, B.L, Carmel, G., Tummino, P.J., Caruso, A., Uria-Nickelsen, M., Mills, D.M., Ives, C., Gib son, R., Merberg, D., Mills, S.D., J iang, Q., Taylor, D.E., Vovis, G.F. \& Trust, T.J . (1999) Genomic-sequence comparison of two unrelated isolates of the humangastric pathogen Helicobacter pylori. Nature 397, 176- 180.

Andersson, J.0. \& Andersson, S.G. (1999) Genome degradation is an ongoing process in Rickettsia. Mol. Biol. Evol. 16, 1178- 1191.

Andersson, J .0. (2000) Evo lu tion ary genomics: is Buchnera a bacterium or an organelle? Curr. Biol. 10, 866- 868.

Andersson, S.G. \& Kurland, C.G. (1998) Reductive evolution of resident genomes. Trends Microbiol. 6, 263- 268.

Andersson, S.G., Zomorodipour, A., Andersson, J.O., Sicheritz-Ponten, T., Alsmark, U.C., Podowski, R.M., Naslund, A.K., Eriksson, A.S., Winkler, H.H. \& Kurland, C.G. (1998) The ge nome se quence of Rick ett sia prowazekii and the origin of mitochondria. Nature 396, 133- 140.

Baldani, J .I., W eaver, R.W ., Hynes, M.F.\& Eardly, B.D. (1992) Utilization of carbon substrates, electrophoretic enzyme patterns, and sym biotic performance of plasmid-cured clover rhizobia. Appl. Envir. Microbiol. 58, 23082314.

Bandi, C., Anderson, T.J ., Genchi, C. \& Blaxter, M.L. (1998) Phy log eny of W olbachia in filarial nematodes. Proc. R. Soc. Lond. B Biol. Sci. 265, 2407- 2413 .

Baumann, P., Baumann, L., Lai, C.Y., Rouhbakhsh, D., Moran, N.A. \& Clark, M.A. (1995) Genetics, physi ol ogy, and evolution ary relationships of the genus Buchnera: Intracellular symbionts of aphids. Annu. Rev. Microbiol. 49, 55- 94.

Berck, S., Perret, X., Quesada-Vincens, D., Prome, J.-C., Broughton, W.J . \& J abbouri, S. (1999) NolL of Rhizobium sp. strain NGR234 is re- quired for 0 -acetyltransferase activity. J. Bacteriol. 181, 957- 964.

Broughton, W.J . \& Perret, X. (1999) Ge neal ogy of legume-rhizobium symbioses. Curr. Opin. Plant Biol. 2, 305- 311.

Brynnel, E.U., Kurland, C.G., Moran, N.A. \& Andersson, S.G. (1998) Evolu tion ary rates for tuf genes in endosymbionts of aphids. Mol. Biol. Evol. 15, 574-582.

Carlson, R.W., Sanjuan, J ., Bhat, U.R., Glushka, J., Spaink, H.P., Wijfjes, A.H., van Brussel, A.A., Stokkermans, T.J ., Peters, N.P.\& Stacey, G. (1993) Thestructures and bi ologi cal activities of the lipo-oligosaccharidenodulation signals produced by type I and II strains of Bradyrhizobium japonicum. J. Biol. Chem. 268, 18372-18381.

Casjens, S. (1998) The di verse and dy namic structure of bacterial genomes. Annu. Rev. Genet. 32, 339- 377.

Chaintreuil, C., Giraud, E., Prin, Y., Lorquin, J., Ba, A., Gillis, M., de Lajudie, P. \& Dreyfus, B. (2000) Photosynthetic bradyrhizobia are nat ural endophytes of the african wild rice Oryza breviligulata. Appl. Environm. Microbiol. 66, 5437- 5447.

Downie, A.J. (1998) Functions of rhizobial nodulation genes; in TheR hizobiaceae. M olec ular Bi ol ogy of M odel Plant-A ssociated Bacteria (Spaink, H.P., K ondorosi, A., Hooykaas, P.J .J ., eds.) pp. 387-402, Kluwer Academic Publishers.

Fraser, C.M., Casjens, S., Huang, W.M., Sutton, G.G., Clayton, R., Lathigra, R., White, O., Ketchum, K.A., Dodson, R., Hickey, E.K., Gwinn, M., Dougherty, B., Tomb, J.F., Fleischmann, R.D., Richardson, D., Peter son, J., Kerlavage, A.R., Quackenbush, J., Salzberg, S., Hanson, M., van Vugt, R., Palmer, N., Ad ams, M.D., Gocayne, J ., Venter, J .C., et al. (1997) Genomic sequence of a Lyme disease spirochaete, Borrelia burgdorferi. Nature $\mathbf{3 9 0}$, 580- 586.

Fraser, C.M., Gocayne, J.D., White, O., Adams, M.D., Clay ton, R.A., Fleischmann, R.D., Bult, C.J ., Kerlavage, A.R., Sutton, G., K elley, J .M., et al. (1995). Themin i mal genecom plement of 
Mycoplasma genitalium. Science $\mathbf{2 7 0}$, 397- 403.

Freiberg, C., Fellay, R., Bairoch, A., Broughton, W.J ., Rosenthal, A. \& Perret, X. (1997) Mo lecular basis of symbiosis between R hizobium and le gumes. Nature 387, 394- 401.

Göttfert, M., Röthlisberger, S., Kündig, C., Beck, C., Marty, R. \& Hennecke, H. (2001) Po ten tial sym bi osis-specificgenes un covered by sequencing a $410 \mathrm{~kb}$ DNA region of the Bradyrhizobium japonicum chromosome. J. Bacteriol. 183, 1405- 1412.

Hacker, J . \& Kaper, J .B. (2000) Pathogenicity islands and the evolution of microbes. Annu. Rev. Microbiol. 54, 641-679.

Handy, J . \& Doolittle, R.F. (1999) An attempt to pinpoint the phylogenetic introduction of glutaminyl-tRNA synthetase among bacteria. J. Mol. Evol. 49, 709- 715.

Hanin, M., J abbouri, S., Quesada-Vincens, D., Freiberg, C., Perret, X., Promé, J .-C., Broughton, W.J . \& Fellay, R. (1997) Sulphation of R hizobium sp. NGR 234 Nod fac tors is de pendent on noeE, a new host-specificity gene. $\mathrm{Mol}$. Microbiol. 24, 1119- 1129.

Hurst, G.D.D., Walker, L.E. \& Majerus, M.E.N. (1996) Bac terial in fec tions of hemocytes as sociated with the maternally inherited male-killing trait in britishpopulations of the two spot ladybird, Adalia bipunctata. J. Invertebr. Pathol. 68, 286- 292.

Hynes, M.F. \& McGregor, N.F. (1990) Two plasmids other than the nodulation plasmid areneces sary for for mation of ni tro gen-fixing nodules by Rhizobium leguminosarum. Mol. Microbiol. 4, 567- 574.

Innes, R.W ., Hirose, M.A. \& Kuempel, P.L. (1988) In duction of ni tro gen-fixingnod ules on clover requires only 32 kilobase pairs of DNA from the Rhizobium trifolii symbiosis plasmid. J. Bacteriol. 170, 3793-3802.

J abbouri, S.B., ReliæB., Hanin, M., Kamalaprija, P., Burger, U., Promé, D., Promé, J.C. \& Broughton, W.J . (1998)nolO and noel (HsnlII) of Rhizobium sp. NGR234 are involved in 3-0-carbamoylation and 2-0-methylation of Nod fac tors.j. Biol. Chem. 273, 12047- 12055.
Kado, C.I. (2000) Therole of the T-pilus in hor i zontal gene transfer and tumorigenesis. Curr. Opin. Microbiol. 3, 643-648.

Kaneko, T., Nakamura, Y., Sato, S., Asamizu, E., Kato, T., Sasamoto, S., W atanabe, A., Idesawa, K., Ishikawa, A., Kawashima, K., Kimura, T., Kishida, Y., Kiyokawa, C., K ohara, M., Matsumoto, M., Matsuno, A., Mochizuki, Y., Nakayama, S., Nakazaki, N., Shimpo, S., Sugimoto, M., Takeuchi, C., Yamada, M. \& Tabata, S. (2000) Com plete ge nome struc ture of the nitrogen-fixing symbiotic bacterium Mesorhizobium loti. DNA R es. 31, 331- 338.

Komaki, K. \& Ishikawa, H. (1999) Intracellular bacterial symbionts of aphids possess many genomic copies per bacterium. J. Mol. Evol. 48, 717- 722 .

Kundig, C., Hennecke, H. \& Gottfert, M. (1993) Correlated physical and genetic map of the Bradyrhizobium japonicum 110 genome. J. Bacteriol. 175, 613-622.

Legocki, A.B., Karºwski, W.M., Podkowiñski, J ., Sikorski, M.M. \& Stêpkowski, T. (1997) Advances in molecular characterization of the yellow lupin-Bradyrhizobium sp. (Lupinus) symbiotic model; in NATO ASI Series, vol. G39: Biological Nitrogen Fixation for E cology and Sustainable Agriculture (Legocki, A.B., Bothe, H. \& Puhler, A., eds.) pp. 263-266, Springer-Verlag, Berlin, Heidelberg.

Lerouge, P., Roche, P., Faucher, C., Maillet, F., Truchet, G., Prome, J .-C. \& Denarie, J . (1990) Symbiotic host-specificity of R hizobium meliloti is de ter mined by a sulphated and acylated glucosamine oligosaccharide signal. Nature 344, 781- 784.

Lin, W.S., Cunneen, T. \& Lee, C.Y. (1994) Sequence analysis and molecular characteriza tion of genes required for the biosynthesis of type 1 cap su lar polysaccharide in Staphylococcus aureus. J. Bacteriol. 176, 7005- 7016.

Lopez-Lara, I.M., van den Berg, J.D., ThomasOates, J .E., Glushka, J ., Lugtenberg, B.J . \& Spaink, H.P. (1995) Structural identification of the lipo-chitin oligosaccharide nodulation. signals of R hizobium loti. Mol. Microbiol. 15, 627- 638. 
Mergaert, P., Van Montagu, M. \& Holsters, M. (1997) M olecular mechanisms of N od factor diversity. Mol. Microbiol. 25, 811-817.

Moran, N.A. (1996) Accelerated evolution and Muller's rachet in endosymbiotic bacteria. Proc. Natl. A cad. Sci. U.S.A. 93, 2873- 2878.

Moran, N.A. \& Wernegreen, J J . (2000) Lifestyle evolution in sym bi otic bacteria: I n sights from genomics. Trends Ecol. Evol. 15, 321- 326.

Moxon, E.R., Rainey, P.B., Nowak, M.A.\& Lenski, R.E. (1994) Adap tiveevo lu tion of highly mu ta ble loci in pathogenic bacteria. Curr. Biol. 4, 24- 33.

Newman, E.B., Budman, L.I., Chan, E.C., Greene, R.C., Lin, R.T., W oldringh, C.L. \& D'Ari, R. (1998) Lack of S-adenosylmethionine results in a cell division defect in E scherichiacoli. J . Bacteriol. 180, 3614- 3619.

Ochman, H., Elwyn, S. \& Moran, N.A. (1999) Cal ibrating bacterial evolution. Proc. Natl. Acad. Sci. U.S.A. 96, 12638- 12643.

Ochman, H., Lawrence, J.G. \& Groisman, E.A. (2000) L at eral gene trans fer and thena ture of bacterial innovation. Nature 405, 299- 304.

Oresnik, I.J ., Liu, S.L., Yost, C.K. \& Hynes, M.F. (2000) Megaplasmid pRme2011a of Sinorhizobium meliloti is not required for vi a bil ity. J. Bacteriol. 182, 3582-3586.

Perret, $X$., Freiberg, C., Rosenthal, A., Broughton, W.J . \& Fellay, R. (1999) High-resolution transcriptional anal y sis of thesym bi otic plasmid of Rhizobium sp. NGR234. Mol. Microbiol. 32, 415- 425 .

Perret, X., Staehelin, C.\& Broughton, W .J . (2000) Molecular basis of symbiotic promiscuity. Microbiol. Mol. Biol. Rev. 64, 180-201.

Preisig, O., Anthamatten, D. \& Hennecke, $\mathrm{H}$. (1993) Genes for a microaerobically induced oxidase com plex in B radyrhizobium japonicum are essential for a nitrogen-fixing endosymbiosis. Proc. Natl. A cad. Sci. U.S.A. 90, 33093313.

Preston, G., Haubold, B. \& Rainey, P.B. (1998) Bacterial genomics and adaptation to life on plants: Im pli cationsfor theevo lu tion of patho- genicityand sym bi osis.Curr. O pin. Microb. $\mathbf{1}$, 589- 597.

Price, N.P.J ., Relic, B., Talmont, F., Lewin, A., Prome, D., Pueppke, S.G., M aillet, F., Denarie, J., Prome, J.C. \& Broughton, W.J. (1992) Broad-host range Rhizobium species strain NGR234 secretes a family of carbamoylated and fucosylated, nodulation signals that are 0 -ac ety lat ed and sulphated. M ol. M icrobiol. 6, 3575- 3584.

Pueppke, S.G. \& Broughton, W.J . (1999) R hizobium sp. strain NGR234 and R. fredii USDA257 share exceptionally broad, nested host ranges. Mol. Plant M icrobe Interact. 12, 293- 318.

Quesada-Vincens, D., Hanin, M., Broughton, W.J . \& J abbouri, S. (1998) In vi tro sulfotransferase activity of NoeE, a nodulation protein of R hizobium sp. NGR234. Mol. Plant M i crobe Interact. 11, 592-600.

Raoult, D. \& Roux, V. (1997) Rickettsioses as par a digms of new or emerging in fectious dis eases. Clin. Microbiol. Rev. 10, 694- 719.

Romero, D., Brom, S., Martinez-Salazar, J., Girard, M.L., Palacios, R. \& Davila, G. (1991) Am pli fi cation and deletion of a nod-nif region in the symbiotic plasmid of R hizobium phaseoli. J. Bacteriol. 173, 2435- 2441.

Rouhbakhsh, D., Lai, C.Y., von Dohlen, C.D., Clark, M.A., Baumann, L., Baumann, P., Moran, N.A. \& Voegtlin, D.J. (1996) The tryptophan biosynthetic pathway of aphid endosymbionts (Buchnera): Ge net ics and evolution of plasmid-associated anthranilate synthase (trpE $G$ ) within the aphididae.J. Mol. Evol. 42, 414-421.

Schlaman, H.R.M., Philips, D.A. \& Kondorosi, E. (1998) Genetic organization and transcriptional regulation of rhizobial nodulation genes; in The R hizobiaceae. M olecularBiology of Model Plant-Associated Bacteria (Spaink, H.P., K ondorosi, A. \& Hooykaas, P.J .J ., eds.) pp. 361-386, Kluwer Academic Publishers.

Segovia, L., Pinero, D., Palacios, R. \& Martinez-Romero, E. (1991) Genetic struc ture of a soil population of nonsymbiotic Rhizobium leguminosarum. A ppl. Environ. M icrobiol. 57, 426- 433. 
Shigenobu, S., W atanabe, H., Hattori, M., Sakaki, Y. \& I shikawa, H. (2000) Ge nome se quence of the endocellular bacterial symbiont of aphids Buchnera sp. APS. Nature 407, 81- 86.

Sikorski, M.M., Stêpkowski, T, Gtviderska, A., Biesiadka, J., fotocka, B., Kopciñska, J., Golinowski, W . \& Legocki, A.B. (1999) Differen tial expression of sym bi osis-related genesin yellow lupine; in Highlights of Nitrogen $\mathrm{Fixa}$ tion Research (Mar ti nez, E. \& Hernandez, G., eds.) pp. 125-129, Kluwer Ac a demic/ Plenum Pub lishers, New York.

Silva, F.J ., van Ham, R.C., Sabater, B. \& Latorre, A. (1998) Structure and evolution of the leucine plasmids car ried by the endosymbiont (Buchnera aphidicola) from aphids of the family Aphididae. FEMS Microbiol. Lett. 168, 43- 49.

Smith, J .M., Smith, N.H., O'Rourke, M.\& Spratt, B.G. (1993) How clonal are bacteria? Proc. Natl. A cad. Sci. U.S.A. 90, 4384- 4388.

Stacey, G., Luka, S., Sanjuan, J., Banfalvi, Z., Nieuwkoop, A.J ., Chun, J., Forsberg, L.S. \& Carlson, R.W . (1994) nodZ, a unique host-specific nodulation gene, is involved in the fucosyl ation of the lipooligosaccharide nodulation signal of Bradyrhizobium japonicum. J. Bacteriol. 176, 620-633.

Stephens, R.S., Kalman, S., Lammel, C., Fan, J ., Marathe, R., Aravind, L., Mitchell, W., Olinger, L., Tatusov, R.L., Zhao, Q., Koonin, E.V.\& Da vis, R.W . (1998) Genomesequence of an ob li gateintracellular patho gen of hu mans: Chlamydia trachomatis. Science282, 754- 759.

Stêpkowski., T., Grviderska, A., Miedzinska, K., Czapliñska, M., Grviderski, M., Biesiadka, J . \& Legocki, A.B. (2001) Molecular and phylogenetic analysis of nodulation genes in Bradyrhizobium sp. WM9 (Lupinus) suggests early di ver gence of "lu pine" lin eage within the B radyrhizobiumgenus. Sub mitted.
Sullivan, J .T. \& Ronson, C.W . (1998) Evolu tion of rhizobia by acquisition of a $500-\mathrm{kb}$ symbiosis island that integrates into a phetRNA gene. Proc. Natl. Acad. Sci. U.S.A. 95, 5145-5149.

Sy, A., Giraud, E., J ourand, P., Garcia, N., Willems, A., de Lajudie, P., Prin, Y., Neyra, M., Gillis, M., Boivin-Masson, C. \& Dreyfus, B. (2001) Methylotrophic Methylobacterium nodulateand fix ni tro gen in sym bi o sis with le gumes. J. Bacteriol. 183, 214-220.

Tomb, J .F., White, O., Kerlavage, A.R., Clayton, R.A., Sutton, G.G., Fleischmann, R.D., Ketchum, K.A., Klenk, H.P., Gill, S., Dougherty, B.A., Nel son, K., Quackenbush, J ., Zhou, L., Kirkness, E.F., Peter son, S., L of tus, B., Rich ard son, D., Dodson, R., Khalak, H.G., Glodek, A., McK enney, K., Fitzegerald, L.M., Lee, N., Adams, M.D., Venter, J.C., et al. (1997) The complete genome sequence of the gastric pathogen Helicobacter pylori. Nature 388, 539- 547 .

Turner, S.L. \& Young, J.P.W. (2000) The glutamine synthetases of rhizobia: Phylogenetics and evolutionary implications. $\mathrm{Mol}$. Biol. Evol. 17, 309- 319.

van Berkum, P. \& Eardly, B.D. (1998) Molecular evolution ary sys tem at ics of the R hizobiaceae; in The Rhizobiaceae. Molecular Biology of M odel Plant-A ssociated Bacteria (Spaink, H.P., Kondorosi, A. \& Hooykaas, P.J .J., eds.) pp. 1-24, Kluwer Aca demic Publishers.

Viprey, V., Del Greco, A., Golinowski, W., Broughton, W .J . \& Perret, X. (1998) Sym bi otic implications of type III protein secretion ma chinery in Rhizobium. Mol. Microbiol. 28, 1381- 1389.

Wernegreen, J .J . \& Moran, N.A. (1999) Evidence for ge netic drift in endosymbionts (B uchnera): Analyses of protein-coding genes. Mol. Biol. Evol. 16, 83-97. 